\title{
REFLECTIONS ON HUMAN RESOURCES IN THE STRATEGY OF RURAL ECONOMIC DEVELOPMENT
}

\author{
Eldon D. Smith*
}

\section{Introduction}

A 1950 paper by Theodore W. Schultz, "Reflections on Poverty within Agriculture", focused professional attention on rural poverty as a public policy issue. We now are quite aware that rural poverty certainly is not a specifically agricultural phenomenon, full-time farm families having diminished to a minuscule component of the total rural population. But its concentration in rural regions still is a reality. Notwithstanding a significant amount of research and a spate of programs to address the problem, especially in the 1960 s, we are not much closer to comprehending it as a public policy issue than when Schultz prepared his 1950 paper.

Unquestionably, the rural scene has changed, and changed dramatically. Even among the rural farm population in many parts of the country more income is contributed by off-farm employment and government transfers than by agriculture. In the Appalachian region, agriculture and forestry have become almost negligible elements of the rural economy. Coal mining and manufacturing predominate as basic sectors, and manufacturing continues to grow despite the incursions of off-shore competition and the declining relative importance of manufactures in the national economy.

What has not changed very much is the general incidence of rural poverty in these regions, a point that will be developed in greater detail later. In addition to the low general productivity of those who are employed, labor utilization rates are scandalously low. An average of onethird of the available labor supply remained unutilized over the previous seven years in a 19-county region in Appalachian Kentucky which was surveyed in 1986 (Preissing,1987,p.216; Preissing and Skees, 1987, p.15),

\footnotetext{
*Professor, Department of Agricultural Economics, University of Kentucky, Lexington. Contributions to the development of the ideas in this paper from several colleagues and associates are gratefully acknowledged. Important among them are Kurt Anschel, Alan DeYoung, Jerry Skees, Louis Swanson and Craig Infanger of the University of Kentucky, Don Larson, Economic Research Service, USDA, and Tom Johnson of Virginia Polytechnic and State University. Responsibility for the final form of the argument rests with the author.
}

despite rapid and virtually uninterrupted growth of total employment over the previous 15 years.

Professor Schultz $(1961,1963)$ also can be credited with awakening the economics profession to the development of the human resource as a neglected facet of economic development literature. The contributions of Gary Becker (1960a\&b) and other familiar names in the field directly or indirectly trace to the intellectual legacy that Schultz initiated in the 1950 s. The Soviet Sputnik satellite of 1957 reawakened American interest in education. But the Sputniks of the 1980s are Volvo, Sony, Nissan, Toyota and the "Made in Korea" (or Hong Kong, or Taiwan) labels on your running shoes and underwear. These have put education high on the policy agenda once again, if not substantively, certainly in current political thetoric. But it also has become a renewed basis of concern among the states and regions which have lagged developmentallyjustifiably so. The evidence is strong that over the past 30 years or so in the historically retarded regions, the rural areas of Central and Southern Appalachia, among others, changes in public policy have not narrowed significantly the disparities in education, rates of poverty or utilization of labor supplies. In fact, there is reason to believe that in the region used for illustrative purposes the absolute quantities of unutilized labor may have increased. Why?

The general hypothesis that is developed in the following pages is founded on very elementary economic concepts. Underlying it is a methodological assumption that these concepts and those of sister disciplines have as a primary function the directing of attention to relevant general categories of relationships. In the main, they have been effective in doing so or they would not be maintained as the conceptual core of the several disciplines. However, if used uncritically, they can direct inquiry away from relationships of strategic significance as readily as toward them. Disciplinary researchers with their specialized conceptual constructs have operated mainly in splendid isolation. In so doing, these constructs have been allowed to direct attention away from, rather than toward, potentially important relationships. These relationships, if understood, quite possibly could enlighten regional economic and human resource development policy. No more stones should be cast at one discipline than at another. We are, to borrow a legal analogy, equally and severally responsible. 


\section{Some Evidence of the Bankruptcy of Past Policies and Theoretical Formulations}

It is exceedingly difficult to provide aggregate evidence of the functioning of the educational establishment that is comparable across states and regions. Different standardized tests, or tests administered at different grades in the scholastic progression, (and/or non-mandatorily) obviate unambiguous comparisons. ${ }^{1}$ Data for the four Central Appalachian states, Kentucky, Tennessee, Virginia and West Virginia suffer from some of these problems. Yet comparisons of the individual systems within these Appalachian states reveal similar patterns as near as one may judge (DeYoung, et al., 1982). Data for a 19county area in Kentucky, the core of which has experienced rapid and almost continuous employment growth, are quite comparable among school districts and are used here for purposes of illustration. It is an area that the University of Kentucky Department of Agricultural Economics and the Economic Research Service, USDA, recently have studied in depth'.

The area to which reference is made includes in its peripheries three predominantly coal-mining counties. Four counties had a mixed base of mining and manufacturing employment in 1980 (but virtually no agriculture), eight had 25 per cent or more of Unemployment-Insurancecovered employment in manufacturing, less than 10 per cent mining (and a moderate size small-farm sector). Four had less than 10 percent employment in either manufacturing or mining, a fair amount of agriculture and forestry, and a large out-commuting population. ${ }^{3}$ Five plants account for 70 percent of manufacturing employment in these latter four. A predominant share of the manufacturing employment of the entire region developed after 1965, about half after 1970.

\section{Effects of Industrial Growth on Labor Utilization}

Nine of these counties with fairly heavy manufacturing components were studied by the Economic Research Service in 1980. They (Larson and White, 1986, p.v.) concluded that as many families had entered the poverty ranks in the 1974-1979 period as had exited from them. Estimates by Stoll (1979) based on national sex, age, education and race adjusted norms for labor force participation indicated that roughly one-third of the available labor supply in the 19-county (broader) area was not being utilized in 1970. The more recent survey of the region indicates that again in 1979-84 one-third of the labor supply was unutilized, and over 13 percent of those who were continuously available for employment had never had a full-time job for a single month (Preissing, pp.88, 216; Preissing and Skees, Table 2, p.15). ${ }^{4}$ Note that this is an area in which there has been what might be termed a small industrial revolution, and all but three counties are accessible by Interstate highways, federal two-lane or four-lane highways or by state toll roads. Total employment has grown substantially after several decades of decline, from 37,700 in 1970 to an average of 85,300 for the 1980-84 period. Manufacturing zoomed from 9,700 to 18,600 over the same period.

\section{The Education Scenario}

For the area as a whole, the education scenario is not encouraging. As Table 1 depicts, dropout rates of those entering ninth grade are extremely high, and learning rates as measured by standardized tests are well below even the generally-recognized low state norms. Educational financing of the schools in the region is slightly below nonAppalachian Kentucky and Appalachian county norms, about 12 percent and 4 percent, respectively. This is true despite 94.4 percent of total revenues being supplied from state and federal allocations, compared to 85.8 percent in non-Appalachian Kentucky. Schools in Whitley county, the site of the most rapid growth of manufacturing employment in the entire region, were singled out for a "scandal" story by Neil Pierce in a September 1987 issue of The Washington Post, referenced in a follow-up article by Kris Fatzone in the Lexington (Kentucky) Herald- Leader November 30, 1987. The combination of increases in employment and infusion of state and federal funds on the basis of ability-to-pay criteria have not been effective strategies in redressing either a deficiency in grades completed or in learning rates.

Why with the almost startling growth of manufacturing and total employment have rates of labor utilization remained so scandalously low, and why have investments in human resource development continued to lag? Why is this true when the fiscal base has expanded and the outflow of the labor resources of the area has been reversed?

Only one thing about this situation is clear: the combined strategies of education and economic development to alleviate either under-investment in human capital or rural poverty and under-utilization of labor largely have failed. New conceptual sightings on these old and troublesome issues are required if relevant policy solutions are to be identified and tested. 
Table 1

Primary and Secondary School Financing and Measures of Performance, School Year 1980-81

\begin{tabular}{|c|c|c|c|c|}
\hline & $\begin{array}{l}\text { Nineteen } \\
\text { Sounth Central } \\
\text { Counties } \\
\text { (All Districts) }\end{array}$ & $\begin{array}{l}\text { Independent } \\
\text { Municipal } \\
\text { Districts }\end{array}$ & $\begin{array}{c}\text { All } \\
\text { Appalachian } \\
\text { Kentucky }\end{array}$ & $\begin{array}{c}\text { All } \\
\text { Kentucky }\end{array}$ \\
\hline $\begin{array}{l}\text { Operating Cost } \\
\text { Expenditures } \\
\text { Per Pupil }\end{array}$ & $\$ 1117$ & $\$ 1235$ & $\$ 1162$ & $\$ 1266^{2}$ \\
\hline $\begin{array}{l}\text { Proportion Entering } \\
\text { Grade } 9 \text { and Completing } \\
\text { Grade } 12\end{array}$ & $56 \%$ & $66 \%$ & $59 \%$ & $70 \%$ \\
\hline $\begin{array}{l}\text { Comprehensive Test } \\
\text { of Basic Skills, percent } \\
\text { Lower than U.S. norms } \\
\text { by more than one Standard } \\
\text { Deviation }{ }^{3} \\
\text { Grade } 10 \\
\text { Grade } 5\end{array}$ & $\begin{array}{l}24 \% \\
23 \%\end{array}$ & $\begin{array}{l}15 \% \\
12 \%\end{array}$ & $\begin{array}{l}20 \% \\
18 \%\end{array}$ & $\begin{array}{l}18 \% \\
11 \%\end{array}$ \\
\hline
\end{tabular}

${ }^{1}$ Only districts included in the Nineteen South Central Counties.

${ }^{2}$ Non-Appalachian Districts only.

${ }^{3}$ Total Battery including verbal and quantatative skills.

\section{Education and Economic Development Policy Analysis-Its Conceptual Legacy}

The Economic Dimensions

Coincident with the so-called "retardation hypothesis" of Professor Schultz in 1950 was the beginning of a fair amount of research interest in the functioning of ruralurban labor markets. (The dissertation research of the author is an example. See Smith, 1954, 1956). What most investigators did not percieve very clearly at that time was the now obvious fact that marketable skills are not homogeneously distributed in space, and inequalities among regions may be exacerbated by an efficiently operating market for developed skills. If capital inputs are unequally distributed in space, the migration process may drain off the most highly developed labor, leaving a concentration of the inferior grades in the countryside, grades that are usable only in low-skill, low-wage industries. An early writer whose name escapes recall termed this "folk depletion." That term captures a relevant dimension of the legacy of problems remaining today in many of the areas that were depopulated rapidly in the 1940s, 1950s and early 1960s.

Later, those interested in rural poverty and regional development became enamored of the discovery of high returns to personal and public investments in human capital formation, an interest that, as noted earlier, is reflected in the work of Becker, Schultz, and many others. Almost concurrently, there was something of a revolt against the circumscriptions of alternatives implicit in central place theory, of which the Schultzian hypothesis could be regarded as a somewhat analytical sub-species. The retardation thesis was turned on its head, so to speak. As an alternative to increasing the efficiency of the rural-urban labor market, attention was turned toward the industrial capital markets and to increasing supplies of capital to regions with under-employed labor. The Tennessee Valley Authority had an industrial development research Division staffed by Stephen Robock, Vernon Ruttan and others before 1952. Rinehart (1963), Moes (1962) and others did early research, and job creation efforts were under way and supported by the Rural Development Program of the USDA in the mid-1950s. The joint KentuckyTennessee efforts (Smith, Deaton and Kelch,1978; Smith, Klindt and Kelch, 1981) followed two decades later. Still more recent is the work of Goode, Hastings and others (Hastings, 1987) based on the massive 13-state data base provided under Hatch Act regional project NE 130. The 
so-called industrial targeting linear probability model from the latter study probabilistically predicts plant locations for 60 groupings of four-digit SICs for any identified community within the region.'

To what conclusion does this legacy of policyoriented studies lead? That the research interpretations supporting pleas for more state and federal aid for schools, better roads and job creation programs have met with some success is apparent. But it also is apparent that the problem formulation and research underlying these pleas was deficient. Hence, a re-examination of the assumptions underlying the formulation is required to identify strategic but as yet neglected dimensions.

Prior formulations implicitly have assumed the following: (1) The supply functions of labor of varying qualities in a particular locale are determined exogenously and independent of local demand. That is, the rate of investment in human capital implicitly is assumed to reflect the operation of a perfect market for these classes of investment, and to reflect productivities outside the region and in futurity. (The failure to invest in the human agent to a level at which marginal costs equate with the present value of future returns simply reflects differences in preferences and aspirations.) (2) There are enough externalized benefits through linkages to other sectors of the local economy to justify public subsidies to induce industrial capital investments in the local economy. (3) These externalities are larger in labor surplus areas than in other areas, especially major metro centers with their apparent diseconomies of large size.

Industrial impact models, including those estimating fiscal impacts, attempt to test assumptions (2) and (3). But impact modeling generally makes no provision for the long term effects, if such there be, of different classes of industry on the development of human resources (and the general social infrastructure) in the affected communities. The fiscal impact models capture some of the effects on capabilities to finance schools, and other human resource services, but do not measure the extent to which these capabilities are translated into enhanced supplies of educational services and/or increased demand and utilization of those services.

The data on employment and labor utilization suggest that in such rural areas there is a large extra-local element in the supply of labor in particular regions. High proportions of local employment opportunities created by industrial development efforts are externalized. At slightly above minimum-wage levels large supplies of better-qualified, non-local labor are available. Otherwise outwardly mobile, but minimally trained, local workers may be induced to stay in the local community if even low-wage jobs are available owing to limited opportunities in external markets. Thus, the effect of industrial expansion is to increase demand for seriously under-trained local labor very little. As those unable to compete for jobs retire and die they appear to be replaced by others who are no more employable. Otherwise, the under-utilization of labor would diminish as local employment expands.

The local income and employment multipliers, both of which are static conceptually, are conventionally assumed to capture the magnitude of the local externality stream. The local fiscal impact models, e.g., the Virginia model of Johnson and Swallow (1987), capture the shortterm benefits and costs to public account. But none of the existing models captures any of the possible effects, negative or positive, on the public supply of, or private demand for educational services and other human capital inputs.

The central point is quite clear and simple. Researchers implicitly have assumed that both supply of and demand for educational services are independent of the type of employment offered by the industries that are induced to locate in the community, and the amounts of employment that they provide in various skill categories. What seems to have been ignored is the idea that the demand for educational services is a behavioral phenomenon that does not reflect with perfect fidelity the capitalized value of the income streams that may be anticipated from human capital investments (part of which are externalized). Instead, it reflects the values and perceptions, indeed a culture, that is conditioned by the economic environment of the locale. Further, this economic environment reflects very imperfectly the economic opportunity set of the general economy with respect to these human capital-enhancing inputs, to say nothing of probable increasing returns over time.

\section{The Education Dimensions}

Viewed from an education perspective, there is a private demand for educational services and a public goods component. The private or family demand for education is expressed through encouragement and assistance in the learning process, parental insistence on regular attendance, praise for good academic performance, and willingness to vote additional taxes to improve the quality of educational services. The public goods component is recognized by legally mandated attendance for a minimum number of years (usually at least up to age 16). Except for forgone earnings, and costs of materials and books (in some cases), the public accepts the significant fiscal burden for nominally "free" public education (including transportation for all who need it). Additionally, there is at least vague recognition that education has something to do with the processes of political democracy and the socialization of the young that contribute to developing a citizenry among whom life can be safe and satisfying. 
The training of teachers, administrators, and counselors, and the salaries offered to them presumably are designed to maximize their contribution to learning. They contribute by developing effective communication skills, through catalyzing curiosity and interest in subject matter, and by soliciting support and understanding of parents in such a manner that the psychological climate for learning is reinforced. But the contributions of educators obviously are constrained to a large degree by the perceived importance attached to education by the public at large that is reflected particularly in the attitudes of students toward learning.

It would be unfair to members of the educational establishment to say that they are unaware that a major component of both public and private demand for educational services is economic, i.e., a perceived derived demand. The qualifier, "perceived", should be emphasized again since perceptions, not realities, are reflected in demand. To their credit, many educators attempt to create awareness of the connection between education and the ability to earn a satisfactory livelihood. But if the signals come from only those who appear to have self-serving interests in: promoting education (and whose exposure to students is a small fraction of their total social exposure even during school hours), one should not expect miracles. Broader exposures in the community-at-large, especially direct exposures to local people who are living demonstrations of the economic value of education seem likely to shift two important elements. In other words, the collective public demand has the potential for (1) modifying the supply of available "free" educational services, shifting it downward and to the right, and (2) shifting the private family and individual demand for the services that are offered upward and to the right.

\section{An Alternative Formation}

Mark Blaug (1980) in his biting methodological critique of conventional economics makes the eloquent and controversial observation (p. 151) "Decision makers do not try to get what they want; they learn to want by appraising what they get. Means and ends are indissolubly related." Human values, in a sense, summarize human knowledge. The public and private values and preferences reflected in the demand for educational services reflect the perceptions of parents, children and the public at large of the consequences of investing in themselves and their fellow citizens. If this is correct, the supply of and demand for human capital are not independent. In the spatially differentiated market for human capital, with its very imperfect information flows over space and community externalities, supply and demand are determined in part by the same local events.
In a much-neglected 1959 University of Chicago doctoral dissertation in economics, Rufus B. Hughes, Jr. developed and tested hypotheses that have a similar underlying logic. The study encompassed rural-urban migration, family-size decisions and on-farm production adjustments to reductions in rural farm population and farm size. In an unpublished 1956 manuscript based on these studies, he says of family size decisions, "A major part of their tendencies...results from the failure of their limited experiences to provide them much understanding of the beneficial effects of education, medical care, etc., upon the economic opportunities of their children" (p. 10). Those oppurtunities are conditioned to a large extent by the social and economic environment in which their perceptions of these opportunities are formed. In personal conversation Hughes referred to these as "demonstration effects." Visible affluence of educated workers who comprise a significantly high proportion of the work force may by demonstration change perceptions and values with respect to education.

To return to the retardation hypothesis of Schultz, it may not be the market for the labor factor as such, i.e., the market for developed productive skills, that is affected adversely by spatial and social separation from the centers of urban-industrial activity. On the contrary, the evidence is fairly strong that signals from the particular local markets that have been surveyed have been transmitted across large distances with amazing efficiency. Large proportions of the growth in employment have been absorbed (1) by workers who had left the region as demand for labor increased and returned, (2) by young adults who otherwise would have left the region and (3) by in-movers.

Instead, the real problem may be in the market for inputs for creating human capital, especially in a breakdown of the information system that informs the children, their parents and the community at large of the rather large long-term rewards for investments in education. Indeed, there is a good deal of evidence that even within the innercity ghetto complexes of larger metro areas this system also is failing seriously.

What is implicit in this alternative formulation? Albert Hirschmans (1958) in The Strategy of Economic Development, outlines a broad framework that focuses on the economic and implicit socio-political externalities of development. Although the specifics of his analysis of the economies of nation-states requires adaptation to generally open, less-developed sub-regions of otherwise developed economies (Smith, 1966), it is relevant to the problem. Negative social externalities are hypothesized for the processes of private investment and job creation resulting from existing rather indiscriminate recruitment policies. An occupational structure that appears to offer economic rewards for education to only a small minority does not 
demonstrate the value of education.

Another much-neglected study by sociologist $\mathrm{H}$. Dudley Plunkettand economist Mary Jean Bowman (1973) provides a basis for hypothesizing that the largely laborintensive, low-skill requiring industries that have been recruited to this and many similar regions do result in negative human capital externalities. The more general arguments of Bowles and Gintis (1976), Collins (1979) and, more recently, by DeYoung (1985) are consistent with the empirical work of Plunkett and Bowman who studied so-called "elites" and concluded (p. 65) that "Outsiders have emphatic and positive views (toward modernization), while natives, though more numerous, are usually indifferent to modernization." Thus, company policy in support of, or counter to progressive change in schools and other social infrastructure may merely reinforce or stifle the already operative predispositions of the types of employees in their workforce. Non-local, educated employees are likely to participate informally and organizationally in community decision processes with a view to upgrading educational opportunities and greater educational achievement if the firm requires educated employees. The objectives of both the establishment managers and their "imported" key employees may be to effect increases in the supply and quality of educational services for their children. However, as Bowles and Gintis suggest, the proprietary interests of management may not al ways be congruent with progressiveness in these regards, especially if the profitability of their enterprise depends on a large supply of untrained, low-cost and immobile labor. The higher average expenditure per pupil, higher rates of completion of secondary schools and superior test scores in the seven independent (municipal) districts in the region suggest that in these districts there quite probably is a concentration of the non-local educated elites to whom Plunkett and Bowman refer.

\section{A Schematic Illustration}

At this point it may be useful to summarize by a diagramatic presentation of the central ideas (Figure 1). The diagram provides a representation of the primary categories of relationships between private investment decisions with respect to industrial enterprises and the linkages through demonstration effects to the demand for and supply of educational services. Figure 1 also represents the direct influences of company policy and the mix of company personnel on private and public decisions with respect to education or human capital investments. It takes the composition of the services sector and the institutional division between local and non-local agencies with fiscal responsibility for financing public education as exogenous and partly derived. It is completely general; it accommo- dates an industry mix that uniformly shares an interest in limiting educational opportunity to preserve a low-cost labor supply, overt efforts to discourage political support for additional tax levies for education, and derived culture that demeans as "high falutin' " the aspirations of individuals and parents to excel academically. At the same time it can accommodate a high-tech industry mix with civically progressive management, with high proportions of professional, technical and managerial manpower, with highly interventionistic social leanings and leadership capabilities, and which clearly demonstrates the potential of the good life through educational investments.

Signals to Local Citizens and Children from the Industry Employment Mix

It is evident that very little is known about these externalities. They have been little discussed in regional economic development literature and scarcely researched at all. But it seems worthwhile, in view of the general hypothesis, to examine the industry mix of the region, the proportions of industry personnel in various categories, and what this would imply if the hypothesis were valid.

In the rural counties of Central Appalachia coal mining, forestry, small farms and manufacturing provide a predominance of basic employment. Small farms traditionally have required only modest educational preparation. But what of mining and manufacturing?

Table 2 provides a breakdown of state and national average skill categories, respectively, for the mining and manufacturing industries that are important in the 19 county survey area. It suggests that, indeed, the classes of industry which predominate in the area utilize very little managerial, professional technical and paraprofessional manpower. There is but one major exception, SIC 35, Machinery Except Electrical.

It is true, of course, that the residentiary sector is larger than the basic goods-producing sector. The private components, especially retail and wholesale trade, and services traditionally have low proportions of occupations requiring more than elementary academic skills. Government, medical, dental, legal, accounting and school personnel require more of these skills. As Plunkett and Bowman show, however, the "home-grown" educated such as school teachers and technicians reared in the same environment tend not to challenge traditional values and standards of educational excellence. In any event, if there is to be a change in the concentration of local visible demonstrations of the contribution of education to productivity and earnings, the primary leverage for that change is through modification of the mix of basic industry, especially manufacturing and export-oriented service industries. $^{6}$ 


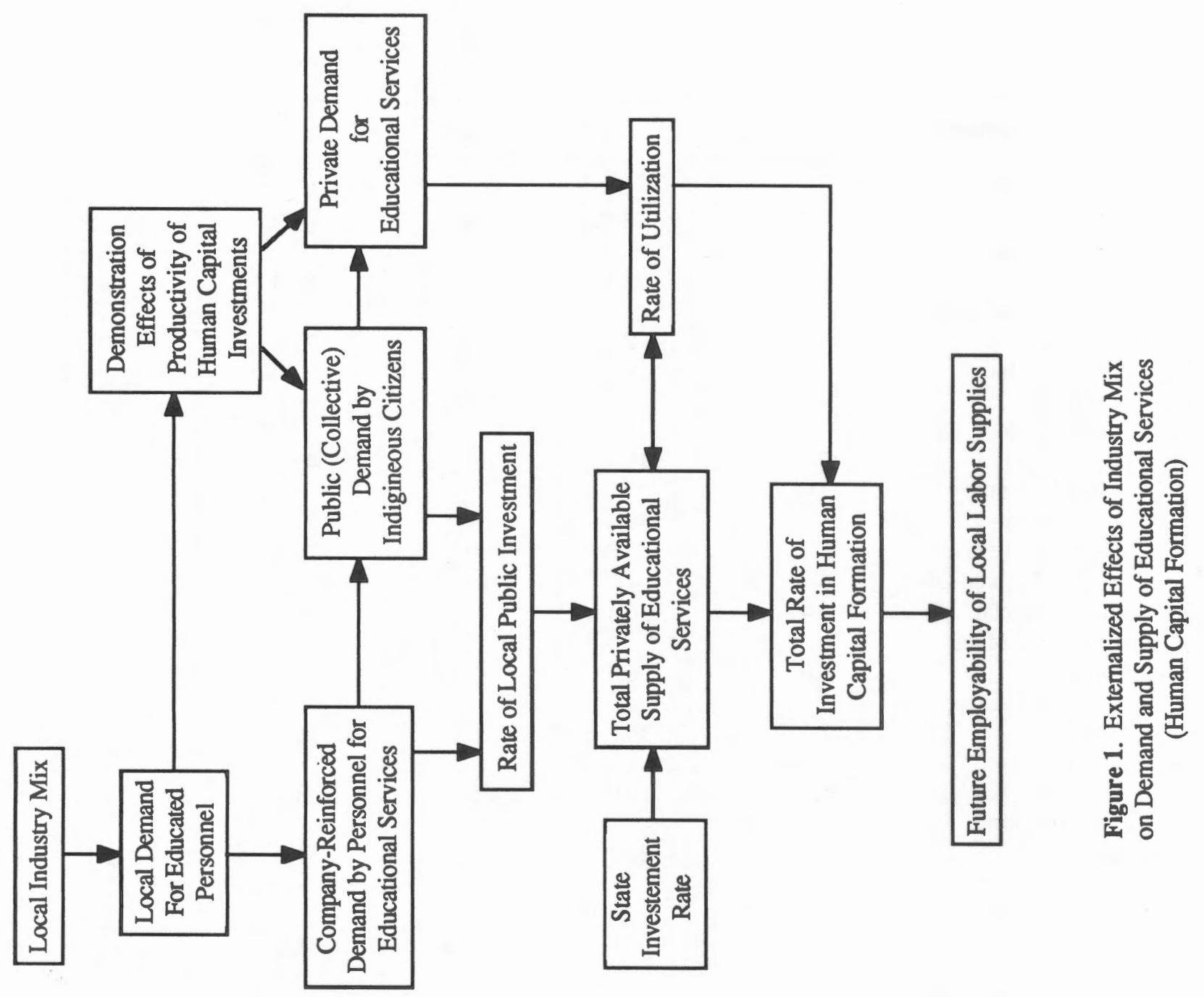


Table 2

Percent Employment in Occupational Classes by Manufacturing and Mining Product Class (SIC), United States Manufacturers and Kentuck Coal Mining

\begin{tabular}{|c|c|c|c|c|c|c|}
\hline SIC & & $\begin{array}{l}(1) \\
\text { Managers \& } \\
\text { Admin. }\end{array}$ & $\begin{array}{c}\text { (2) } \\
\text { Professional } \\
\text { Para-Prof. \& } \\
\text { Technical }\end{array}$ & $\begin{array}{c}(3) \\
\text { Total } \\
1 \& 2\end{array}$ & $\begin{array}{c}(4) \\
\text { Production } \\
\text { Conversion \& } \\
\text { Mat. Handling }\end{array}$ & $\begin{array}{c}(5) \\
\text { Proportion } \\
\text { All Mfg. } \\
\text { Employees in } \\
\text { Survey Area } \\
(1980-84)^{*}\end{array}$ \\
\hline \multirow[t]{2}{*}{20} & Food and Kindred & & & & & \\
\hline & Products & $4.8 \%$ & $3.6 \%$ & $8.4 \%$ & $73.7 \%$ & $9.64 \%$ \\
\hline \multirow[t]{2}{*}{22} & Textile Mill & & & & & \\
\hline & Products & 3.5 & 2.7 & 6.2 & 82.7 & 5.92 \\
\hline \multirow[t]{2}{*}{23} & Apparel and Textile & & & & & \\
\hline & Products & 3.1 & 1.5 & 4.6 & 83.7 & 34.13 \\
\hline \multirow[t]{2}{*}{24} & Lumber and Wood & & & & & \\
\hline & Products & 4.7 & 2.1 & 6.8 & 72.8 & 9.09 \\
\hline \multirow[t]{2}{*}{25} & Furniture and & & & & & \\
\hline & Fixtures & 4.5 & 2.5 & 7.0 & 79.9 & 2.24 \\
\hline \multirow[t]{2}{*}{27} & Printing and & & & & & \\
\hline & Publication & 7.1 & 11.5 & 18.6 & 46.8 & 3.09 \\
\hline \multirow[t]{2}{*}{28} & Chemicals and & & & & & \\
\hline & Allied Products & 8.2 & 19.2 & 27.4 & 51.9 & 3.00 \\
\hline 30 & Rubber and Plastics & 5.7 & 5.0 & 10.7 & 76.9 & 1.15 \\
\hline 32 & Stone, Clay and Glass & 5.9 & 4.7 & 10.6 & 76.0 & 4.45 \\
\hline 33 & Primary Metals & 4.4 & 6.5 & 10.9 & 76.5 & 2.27 \\
\hline \multirow[t]{2}{*}{34} & Fabricated Metal & & & & & \\
\hline & Products & 6.0 & 6.8 & 12.8 & 73.8 & 1.80 \\
\hline \multirow[t]{2}{*}{35} & Machinery, except & & & & & \\
\hline & Electrical & 7.4 & 16.8 & 24.2 & 56.9 & 10.19 \\
\hline \multirow[t]{2}{*}{36} & Electrical and & & & & & \\
\hline & Electronic Machinery & 6.1 & 19.9 & 26.0 & 58.7 & 2.31 \\
\hline \multirow[t]{2}{*}{37} & Transportation & & & & & \\
\hline & Equipment & 5.4 & 20.2 & 25.6 & 51.0 & 1.12 \\
\hline \multicolumn{7}{|c|}{$\begin{array}{l}\text { Estimated Weighted Mean } \\
\text { of Manufacturing SIC's }\end{array}$} \\
\hline \multicolumn{2}{|c|}{ shown above."* } & & & 10.34 & 74.5 & \\
\hline \multirow[t]{2}{*}{12} & Kentucky Bituminous \& & & & & & \\
\hline & Lig. Coal Mining ${ }^{* * *}$ & 6.4 & 3.7 & 10.1 & 83.8 & \\
\hline
\end{tabular}

Sources: 1. U.S. Dept. of Labor. Occupational Employment in Manufacturing Industries. Bulletin 2248. Washington, D.C.: Bureau of Labor Statistics, 1985.

2. Kentucky Cabinet for Human Resources. Kentucky Occupational Profiles - Construction and Mining, 1981 Frankfort: Research and Statistics Branch, 1985.

3. Manufacturing Proportion from Special Tabulation for 1980-84, Kentucky Cabinet for Human Re sources, Frankfort, KY.

"Presents the proportions of employees within the manufacturing sector, i.e., 9.64\% of the employment in the manufacturing sector is in Food and Kindred Products in the Kentucky Survey Area. Not shown are classes of manufacturing with less than 5 firms, proportions are of average total manufacturing employment and do not total to $100 \%$.

- Based on assumed similarity of regional distribution with U.S. distribution of occupational classes. Comparison of survey data with U.S. data for SIC 20, 23, 24 and 35 indicated approximately similar proportions.

*Not considered in the manufacturing sector. 
That to be selective in regard to industries recruited into such communities is not costless is obvious. Initially those establishments requiring large complements of educated personnel necessarily will bring with them more personnel from outside the community. This translates into fewer jobs for local personnel and probably into greater requirements for social services to attract nonlocal employees. Moreover, the inducements required to recruit such industries are likely to be much greater per job created. A small complement of industries with higher proportions of educated classes of personnel has located in this region, however. This has occurred despite substandard educational achievement and attainment and suggests that there is at least a modicum of latitude for selective recruiting. Estimates of comparative probabilities of new locations of industrial establishments are available for 60 4-digit SIC groupings for Virginia, West Virginia and the Northeastern states. A set of illustrative estimates for a small set of communities in Virginia, West Virginia and Pennsylvania provides evidence that probabilities of new locations of industries with quite variable education requirements are not greatly dissimilar in some, although not all, Appalachian communities. ${ }^{7}$ This suggests at least the possibility that there may be important tradeoffs between larger complements of indiscriminately recruited jobs and smaller ones that have, if the hypothesis is correct, longer range possibilities for breaking the vicious cycle of low levels and qualities of education, severe underutilization and low productivity of labor, low skill demanding employers, and re-inforcement of the low standards of investment in human capital.

\section{Summary and Conclusions}

The ideas presented here are speculative and supported only by suggestive and illustrative evidence. It may well be that the cultural legacy of Appalachia is such that there is little latitude for even modest intergenerational reorientation to make the human- capital-producing enterprise function in a manner congruent with the demands of a dynamic society. But one thing is very clear. There is a common interest in this and other regions with similar problems. Through progressive tax systems and compensatory systems for financing education and other services all regions pay the price of the retardation of these areas. Benefits to local school systems in this 19-county region amounted annually to over $\$ 3,600,000$ more than they would have if they had received allocations equivalent to non-Appalachian Kentucky counties, according to data from DeYoung, et al. (1982). Unemployment compensation and income maintenance payments amounted to over $\$ 500$ per capita for several counties (Peters, 1988, p.68). Costs of highway maintenance, medical benefits and other services obviously are borne disproportionately outside the region. Externalized public sector costs of rural poverty and under-investment in the human capital of the region are very large. And, from the available evidence, it is overwhelmingly obvious that the strategy for regional development of the economy and its human resources needs a new look. The profession needs to question the theoretical legacy that has led in the direction of what appears to be an impoverished formulation of the problem of regional impoverishment.

What is obvious is that the general public and we as a profession have relied on policies that have not worked; they apparently have notembraced relationships genuinely strategic to the solution of the problem. This paper is based on the supposition that these scientists have been trapped by an uncritical acceptance of prior theoretical formulations, and that there is a need to break out of these constraints if creatively functional solutions to these old problems are to be found. The economics profession clearly has failed to meet this challenge. Regrettably, there is very little evidence that recent entrants into the profession have been inclined to question these prior formulations.

\section{Notes}

${ }^{1}$ Corrupt practices in the administration of tests to avoid revealing inadequate performance have been alleged but are not substantiated as a major problem, to the knowledge of the author.

${ }^{2}$ The University of Kentucky study was initiated in 1986 under cooperative agreement with the Economic Research Service and the Economic Development Administration. The ERS survey was in 1980 and covered the nine core counties of the region (Larson and White, 1986).

${ }^{3}$ County economic base classes are: (1)coal: Clay, Leslie and Perry; (2) mixed coal and manuf acturing: Bell, Knox, McCreary, and Whitley; (3)manufacturing: Adair, Casey, Clinton, Cumberland, Laurel, Russell, Pulaski and Wayne; (4) other: Jackson, Lincoln, Owsley and Rockcastle.

The 16 percent figure quoted in Preissing and Skees is an unweighted average in which continuously employed persons are under-represented.

${ }^{5} \mathrm{~A}$ limitation of these models is that the employment size range is not constrained, and an establishment of one or more employees sometime during a ten-year time period is treated as an equivalent location occurrence and coded as a positive value in the location dichotomy. Location incentives such as low-cost financing availability, industrial site availability and public-supported training grants, are not included as hypothetical location determinants. The models are, notwithstanding these limitations, the best available source of insight.

Opportunities for altering the mix of import-substituting industries, e.g., finance and medical services are notoriously con- 
strained by size economies and local demand as affected by income and its distribution.

'Unpublished estimates provided by Dr. Frank Goode, Pennsylvania State University. Data for the linear probability models were compiled under the co-ordination of Dr. Goode by participants in USDA, Cooperative State Research Service Regional Project NE 130.

\section{References}

Becker, Gary S. "Underinvestment in Education?" American Economic Review, L(May 1960a) 346 - 354.

- Human Capital: A Theoretical and Empirical Analysis with Special References to Education. New York: National Bureau of Economic Research, 1960b.

Blaug, Mark. The Methodology of Economics. Cambridge: Cambridge University Press, 1980.

Bowles, S. and Gintis, H. Schooling in Capitalist America. New York: Basic Books, 1976.

Collins, R. The Credential Society. New York: Academic Press, 1979.

DeYoung, Alan. "Economic Development and Educational Status in Appalachian Kentucky". Comparative Education Review, 29(1)February 1985. 27-67.

DeYoung, Alan, Charles Vaught, James O'Brien and Jean Brymer. Educational Performance in Central Appalachia - Statistical Profiles of Appalachian and Non-Appalachian School Districts. Final Report for The Appalachian Regional Commission Project. "Monitoring Appal achian School Performance" Lexington: University of Kentucky, Appalachian Center, March 1982.

Hastings, Steven E. "Description of Industrial Classification and the Input Availability and Output Demand Variables Used in the Northeast Industrial Targetting and Economic Development Data Base System", Newark: University of Delaware, Food and Natural Resources Department, 1987. Unpublished.

Hirshman, Albert. The Strategy of Economic Development. New Haven: Yale University Press, 1958.

Hughes, Rufus B.,Jr. Low Incomes in Southem Agriculture Population Adjustments. Ph.D. Dissertation. Chicago: University of Chicago, Department of Economics, 1959.

Johnson, Thomas and Brent Swallow. "A Fiscal Impact Model for Virginia Counties", Review of Regional Studies 17(1) Spring '87. 67-74.

Larson, Donald K. and Claudia White. Will Employment Growth Benefit All Households? A Case Study in Nine Kentucky Counties, Rural Development Research Report 55. Washington, DC: USDA, ERS, January 1986.

Moes, J.E. Local Subsidies to Industry. Chapel Hill: University of North Carolina Press. 1962.
Peters, David. Employment Instability During a Recession in Selected Non-metro Kentucky Counties: Evidence of Factors Determining Employment Instability at the Manufacturing Firm Level. M.S. Thesis. Lexington: University of Kentucky, Department of Agricultural Economics, 1988.

Plunkett, H. Dudley, and Mary Jean Bowman. Elites and Change in the Kentucky Mountains. Lexington: University Press of Kentucky, 1973.

Preissing, John. Employment Instability for Selected Non-Metropolitan Kentucky Counties During a Recession: The Influence of Personal Characteristics of Workers. M.S. Thesis. Lexington: University of Kentucky, Department of Agricultural Economics, 1987.

Preissing, John and Jerry Skees. Problems with Unemployment Estimates for Rural Areas. Staff Paper No. 232, Lexington: University of Kentucky, Department of Agricultural Economics, 1987.

Rinehart, James. "Rates of Return on Municipal Subsidies to Industry", Southern Economics Journal 29(4), 1963. 297. 306.

Schultz, Theodore W."Reflections on Poverty within Agriculture." Journal of Political Economy. 58(1), 1950. 1-15.

. "Education and Economic Growth", in Social Forces Influencing American Education. Nelson Chenery, Editor, Chicago: University of Chicago Press, 1961.

. The Economic Value of Education. New York: Columbia University Press, 1963.

Smith, Eldon D. Urban Adjustments of Rural Migrants in Indianapolis: Problems and Possibilities of Long Distance Migration, Ph.D. Thesis. Madison: University of Wisconsin, Department of Agricultural Economics, 1954.

"Restrictions on Policy Altematives Relating to Underdeveloped Regions of Developed Countries", December 1966, Journal of Farm Economics, 48(5).1227-1231.

" "Nonfarm Employment Information for Rural People" Joumal of Farm Economics. XXXVIII, (3) August 1956, 813-827.

Smith, Eldon D., Brady Deaton and David Kelch. "Locating Determinants of Manufacturing Industry in Rural Areas," Southern Joumal of Agriculural Economics 10(1), 1978. 23-32.

Smith, Eldon D., Thomas R. Klindt and David Kelch, Industrial Location and Growth in Submetro Tennessee and Kentucky Communities. Southern Cooperative Series Bulletin 258, Knoxville: University of Tennessee, Agricultural Experiment Station, 1981.

Stoll, John R. Rural Manufacturing Plant Employment Growth in Kentucky and Tennessee: The Effects of Community and Regional Characteristics. M.S. Thesis. Lexington: University of Kentucky, Department of Agricultural Economics, 1977. 